\title{
PENGARUH KEPEMIMPINAN ETIS TERHADAP VOICE BEHAVIOR DENGAN IDENTIFIKASI ORGANISASIONAL SEBAGAI PEMEDIASI
}

\author{
Utami Tunjung Sari* ${ }^{1}$ \\ Cahya Purnama Asri ${ }^{1}$ \\ Aurel Katrin Medina ${ }^{1}$ \\ ${ }^{1}$ Program Studi Kewirausahaan, Universitas Widya Mataram, Indonesia
}

\begin{abstract}
Ethical leadership arises as a result of various ethical violations and demands for leaders to be able to manage ethical accountability. This study describes the mechanism of the influence of ethical leadership behavior on voice behavior in private sector organizations in Indonesia. This study attempts to look at the role of organizational identification as mediating the influence of ethical leadership on voice behavior. Social learning, social exchange, and social identity theory are used as the foundation in this study. 131 valid responses from employees took part in the study. he results of data analysis show that ethical leadership behavior has a positive influence on voice behavior. Furthermore, organizational identification mediates the influence of ethical leadership on voice behavior. This finding shows that ethical leadership enhances organizational identification and employees identified with organizations have a tendency to do voice behavior.
\end{abstract}

Keyword: Ethical leadership; Organizational Identificatio; Voice Behavior

\begin{abstract}
Abstrak
Kepemimpinan etis muncul sebagai akibat dari berbagai pelanggaran etika dan tuntutan bagi pemimpin untuk dapat mengelola akuntabilitas etis. Penelitian ini menjelaskan mekanisme pengaruh perilaku kepemimpinan etis terhadap voice behavior pada organisasi sektor swasta di Indonesia. Penelitian ini mencoba untuk melihat peran identifikasi organisasional sebagai pemediasi pada pengaruh kepemimpinan etis terhadap voice behavior. Teori pembelajaran, pertukaran sosial, dan identitas sosial, digunakan sebagai landasan dalam penelitian ini. 131 tanggapan valid dari karyawan ikut ambil bagian dalam penelitian ini. Hasil analisis data menunjukkan perilaku kepemimpinan etis memiliki pengaruh positif pada voice behavior. Selanjutnya, identifikasi organisasional memediasi pengaruh kepemimpinan etis pada voice behavior. Temuan ini menunjukkan bahwa kepemimpinan etis meningkatkan identifikasi organisasional dan karyawan yang teridentifikasi dengan organisasi memiliki kecenderungan untuk melakukan voice behavior.
\end{abstract}

Kata Kunci: Identifikasi Organisasional; Kepemimpinan Etis; Voice Behavior;

Article History: Received: (08-08-2020); Revised: (05-10-2020); and Published: (31-10-2020)

Copyright $@ 2020$ Utami Tanjung Sari, Cahya Purnama Asri, Aurel Katrin Medina

How to cite this article: Sari, U.T., Asri, C.P., dan Medina, A.K (2020). Pengaruh Kepemimpinan Etis terhadap Voice Behavior dengan Identifikasi Organisasional sebagai Pemediasi. Managament Insight: Jurnal IImiah Manajemen. 15(2), 208-220

Retrevied from: https://ejournal.unib.ac.id/index.php/Insight 


\section{PENDAHULUAN}

Kepemimpinan sering dipilih sebagai pendorong penting etika dan perilaku tidak etis di dalam organisasi (Brown \& Treviño, 2006; Brown \& Mitchell, 2010). Brown dan Trevino (2006) menyatakan bahwa bagaimana pemimpin dapat mempengaruhi perilaku etis karyawan adalah esensi dari kepemimpinan yang efektif. Perilaku etis merupakan studi tentang perilaku benar dan salah dalam konteks organisasi (Mayer, Kuenzi, \& Greenbaum, 2010). Studi empiris dalam beberapa dekade terakhir, menyoroti efektivitas kepemimpinan etis dalam mendorong perilaku etis karyawan (Brown, Treviño, \& Harrison, 2005; Demirtas, 2013), meningkatkan kinerja (Walumbwa et al., 2011), serta perilaku menyimpang dan tidak etis (Mayer et al., 2010).

Selain dapat meningkatkan kinerja tugas karyawan kepemimpinan etis juga membantu mempromosikan perilaku peran ekstra yang melebihi peran utama karyawan. Kepemimpinan etis, yang menekankan aspek etika kepemimpinan, dapat diidentifikasi sebagai anteseden penting untuk berbagai jenis perilaku peran ekstra. Salah satu prediksi sentral dari kepemimpinan etis adalah menyediakan komunikasi dua arah untuk karyawan. Komitmen kepemimpinan etis pada komunikasi dua arah dan mendengarkan karyawan merupakan prediktor penting dari voice behavior (Tang, 2016).

Beberapa studi empiris mengenai kepemimpinan etis dan kinerja peran ekstra, diantaranya kepemimpinan etis dan multi-level OCB (Lu \& Lin, 2014; Mayer et al., 2010; Newman, Kiazad, Miao, \& Cooper, 2014; Resick, Hargis, Shao, \& Dust, 2013; Stouten, van Dijke, Mayer, De Cremer, \& Euwema, 2013) dan perilaku menolong (Kalshoven, Den Hartog, \& de Hoogh, 2013). Namun demikian, penelitian mengenai pengaruh kepemimpinan etis terhadap voice behavior masih sangat terbatas sehingga masih memerlukan dukungan empiris (Tu \& Lu, 2016).

Manajer puncak memerlukan informasi dari karyawan pada tingkat yang lebih rendah terutama dalam kondisi bisnis yang dinamis. Voice behavior dikonsepkan sebagai salah satu tipe perilaku peran ekstra karyawan yang dapat menunjukkan letak permasalahan dan memberikan saran atau jalan keluar yang konstruktif ke arah yang lebih baik (LePine \& Van Dyne, 1998; Morrison, 2011). Voice behavior dianggap penting untuk deteksi dini masalah serius dan penciptaan perbaikan, serta peluang inovasi dalam organisasi (Detert \& Burris, 2007).

Beberapa penelitian berfokus pada kepemimpinan etis dan kinerja peran ekstra, namun demikian berbagai topik masih perlu dieksplorasi dalam domain kepemimpinan etis dan kinerja peran ekstra. Sebagian besar studi kepemimpinan etis dan peran ekstra berfokus pada mengeksplorasi mekanisme psikologis dengan menggunakan teori pembelajaran sosial dan teori pertukaran sosial sehingga mengabaikan proses kognitif dan relevansi dari teori lain (Tu \& Lu, 2016). Selain itu, urgensi untuk mengeksplorasi mekanisme pada pengaruh kepemimpinan etis terhadap voice behavior dikarenakan beberapa penelitian mengenai kepemimpinan etis dan voice behavior berfokus pada faktor kontekstual seperti misalnya budaya etis dan voice climate yang diyakini dapat membentuk konteks fasilitasi untuk terlibat dalam voice behavior (Bai, Lin, \& Liu, 2019; Tang, 2016; Walumbwa \& Schaubroeck, 2009).

Beberapa peneliti menyarankan untuk menambahkan beberapa faktor, seperti sikap, disposisi, dan persepsi individu untuk melengkapi faktor situasional dalam menjelaskan terbentuknya voice behavior (Bai et al., 2019). Lebih lanjut, (Bai et al., 2019) juga menyatakan masih perlu untuk melihat faktor disposisional individu dalam pengaruh kepemimpinan etis terhadap voice behavior, seperti misalnya identifikasi organisasional. Walumbwa et al. ( 2011) mempelopori penelitian dengan menggunakan identifikasi organisasional sebagai mediator pengaruh kepemimpinan etis pada kinerja. Dalam penelitiannya, (Walumbwa et al., 2011)menyatakan bahwa identifikasi organisasional membantu untuk menjelaskan pengaruh kepemimpinan etis pada kinerja karyawan. Dengan demikian, terdapat indikasi adanya peran 
pemediasi identifikasi organisasional dalam mekanisme kepemimpinan etis terhadap voice behavior.

Berbeda dengan teori pembelajaran sosial (Bandura, 1977) dan teori pertukaran sosial (Blau, 1964), teori identitas sosial juga perlu dipertimbangkan untuk menjelaskan pengaruh kepemimpinan etis pada keluarannya (Yang, 2014). Dengan berdasar pada teori identitas sosial, seorang individu tidaklah dianggap sebagai individu secara mutlak satu dalam kehidupannya. Individu merupakan bagian dari kelompok tertentu baik disadari maupun tidak disadari. Konsep identitas sosial adalah bagaimana seseorang itu secara sosial dapat didefinisikan (Ellemers, De Gilder, \& Haslam, 2004). Konsep tersebut berangkat dari asumsi umum yaitu setiap individu selalu berusaha untuk membentuk konsep diri yang positif. Menurut teori identitas sosial, individu cenderung untuk menemukan identitas sosial (yang berarti 'siapa saya') dalam hubungan sosial dengan organisasi mereka (Ellemers et al., 2004).

Kepemimpinan etis memainkan peran agen moral organisasi dan menyampaikan nilai dan sasaran yang berfokus pada organisasi secara etis (van Gils, Van Quaquebeke, van Knippenberg, van Dijke, \& De Cremer, 2015). Beberapa studi menyoroti beberapa bukti yang relevan untuk mendukung gagasan tersebut. Misalnya, orang lebih mengenal kelompok dan organisasi, karena tokoh kunci identitas (yaitu pemimpin etis) yang dapat dipercaya, berorientasi pada kerjasama, terbuka dan secara proaktif mempromosikan perilaku etis (Ashforth, Harrison, \& Corley, 2008).

Identifikasi karyawan meningkat ketika para pemimpin mereka dicirikan oleh atribut yang disebutkan di atas. Dengan demikian, dapat disimpulkan bahwa pemimpin etis dapat mendorong identifikasi karyawan dengan organisasi dan memotivasi mereka untuk berperforma lebih baik (DeConinck, 2015; Van Knippenberg, 2000), melakukan voice yang konstruktif (Yang dan Liu, 2014), mengurangi turnover intention (DeConinck, 2015), dan meningkatkan kepuasan kerja serta kecenderungan mereka untuk menampilkan perilaku kewargaan organisasional (Ogunfowora, 2014).

Identifikasi organisasional dapat memberikan dampak positif bagi perusahaan seperti kooperatif dan partisipatif dalam pengambilan keputusan, motivasi intrinsik, sharing informasi dan koordinasi, kinerja kerja, kepuasan pada pekerjaan, perilaku peran ekstra, evaluasi positif pada organisasi dan membela organisasi (Van Knippenberg \& Sleebos, 2006). Lebih lanjut, Choi et al. (2014) menyatakan bahwa karyawan yang mengidentifikasi diri dengan organisasi melalui penemuan identitas sosial mereka akan melihat kepentingan organisasi sebagai kepentingan mereka (Van Knippenberg, 2000).

Penelitian ini dilakukan pada konteks organisasi/perusahaan pada sektor swasta yang bersifat profit di Indonesia. Pemilihan sektor swasta yang bersifat profit didasarkan pada hasil survei yang dilakukan oleh DDI (Daya Dimensi Indonesia) pada tahun 2016 yang menyatakan bahwa perusahaan sektor swasta di Indonesia menghadapi persaingan yang semakin ketat di era perdagangan bebas (id.beritasatu.com). Oleh karena itu, perusahaan dituntut untuk melakukan inovasi terus-menerus. Peningkatan keahlian, kreativitas dan inovasi juga harus melibatkan para karyawan. Voice behavior merupakan salah satu prediktor dari inovasi dan peluangperbaikan. Oleh karena itu, penelitian mengenai voice behavior lebih tepat dilakukan pada sektor swasta mengingat dinamika persaingan yang terjadi pada sektor tersebut. Selain itu, dalam survei terhadap 12.423 pemimpin di sejumlah perusahaan swasta di Indonesia didapatkan hasil bahwa kualitas dari pimpinan masih perlu ditingkatkan, hanya $38 \%$ yang menyatakan kualitas kepemimpinan di perusahaannya memiliki kategori baik atau luar biasa (id.beritasatu.com). Oleh karena itu, penelitian ini bertujuan untuk melihat efektivitas penerapan kepemimpinan etis pada sektor organisasi swasta di Indonesia. 
Berdasarkan pada beberapa literatur dan temuan beberapa peneliti yang telah dikemukakan di atas, peneliti mencoba untuk menambah dukungan empiris dalam penelitian kepemimpinan etis dengan melihat pengaruhnya pada kinerja peran ekstra berupa voice behavior. Selain itu, teori identitas sosial perlu dieksplorasi untuk menjelaskan pengaruh kepemimpinan etis terhadap perilaku peran ekstra, melengkapi teori pembelajaran dan pertukaran sosial serta mengeksplorasi mekanisme kepemimpinan etis dan voice behavior melalui identifikasi organisasional.

\section{TINJAUAN PUSTAKA VOICE BEHAVIOR}

Voice behavior didefinisikan sebagai perilaku menyuarakan ide, gagasan, informasi, atau saran mengenai permasalahan yang ada dalam lingkungan kerja yang tidak terdapat dalam deskripsi pekerjaan perusahaan dan diungkapkan kepada orang lain yang memiliki wewenang untuk mengambil keputusan tertentu terkait informasi tersebut dengan tujuan membawa organisasi atau perusahaan ke arah yang lebih baik (Morrison, 2011). Ada tiga karakteristik yang melekat pada voice behavior, yaitu diskresioner (tidak disyaratkan oleh organisasi atau manajemen atau tidak diuraikan dalam satu deskripsi pekerjaan), berorientasi tantangan (bertujuan mengubah status quo dan membuat perubahan yang konstruktif), dan beresiko (terkait dengan ketidaknyamanan, mendapatkan citra publik atau label negatif, merusak hubungan dengan orang lain dan dengan demikian merusak hubungan sosial). Dikarenakan risiko tinggi dari voice behavior, karyawan lebih cenderung tetap diam daripada menyuarakan pikiran mereka (Milliken et al, 2003;. Morrison \& Milliken, 2000). Ketika ini terjadi, pengambil keputusan kunci tidak memiliki informasi yang mereka butuhkan untuk membuat keputusan yang tepat atau memperbaiki masalah yang serius.

Terdapat dua keyakinan inti yang mendasari seseorang untuk melakukan voice behavior (Morrison, 2011). Salah satu keyakinan ini adalah apakah seseorang percaya bahwa masukan dan sarannya akan didengarkan dan ditindaklanjuti (Detert \& Burris, 2007; Morrison, 2011). Keyakinan inti lainnya adalah mengenai keamanan ketika melakukan voice behavior, dengan kata lain apakah orang-orang akan berbicara tanpa sanksi.

\section{KEPEMIMPINAN ETIS}

Pada tahun 2005, Brown et al. memperkenalkan sebuah konsep deskriptif mengenai kepemimpinan etis dan mendefinisikannya sebagai demonstrasi perilaku yang tepat secara normatif melalui tindakan personal dan hubungan interpersonal, dan promosi perilaku tersebut kepada pengikut melalui komunikasi, penguatan dan pengambilan keputusan dua arah. Definisi kepemimpinan etis tersebut juga telah banyak digunakan pada banyak penelitian (Resick et al., 2013; Stouten et al., 2013; Walumbwa et al., 2011).

Studi awal yang berfokus pada kepemimpinan etis sebagai gaya tersendiri dilakukan oleh (Treviño, Brown, \& Hartman, 2003) yang menggambarkan kepemimpinan etis terdiri dari dua pilar utama: menjadi orang yang bermoral (moral person) dan menjadi manajer yang bermoral (moral manager). Moral person mengacu pada kualitas dari kepemimpinan etis sebagai orang yang bekerja, seperti kejujuran, kepercayaan, keadilan, dan perhatian pada orang lain. Konsep moral manager merujuk 
pada bagaimana kepemimpinan etis menggunakan peran manajerial dan posisi kepemimpinan untuk mempromosikan etika di tempat kerja, misalnya melalui pemodelan perilaku etis, setting dan komunikasi standar etika, serta menggunakan penghargaan dan hukuman untuk memastikan bahwa standar etika diikuti.

Kepemimpinan etis sangat menekankan komunikasi dua arah yang artinya bahwa pemimpin tidak hanya fokus pada pendapatnya sendiri, tetapi juga harus mau mendengarkan, dan menerima pendapat dari karyawan. Hal tersebut menunjukan bahwa kepemimpinan etis memiliki rasa peduli, dan respon sosial yang baik (Brown et al., 2005). Sementara itu, yang dimaksud dengan penguatan (reinforcement) dalam definisi tersebut adalah pemimpin mampu menetapkan standar etika dan mendisiplinkan karyawan yang melanggar etika. Sedangkan untuk pengambilan keputusan, hal itu diartikan bahwa pemimpin sadar akan konsekuensi etis dari keputusan yang mereka buat, berprinsip serta adil, dan berlaku untuk siapa saja.

\section{IDENTIFIKASI ORGANISASIONAL}

Konsep identifikasi organisasional merupakan konsep yang dibangun atas dasar teori identitas sosial untuk menjelaskan hubungan antara anggota organisasi dengan organisasi (Ashforth et al., 2008). Identitas sosial dapat didefinisikan sebagai konsep diri yang dimiliki individu yang terdiri atas kesadaran akan status keanggotaan yang dimiliki individu sebagai anggota grup sosial dan bersama dengan nilai serta makna emosional yang melekat pada keanggotaanya (Ashforth et al., 2008) Lebih lanjut, (Ashforth et al., 2008) menyatakan bahwa identifikasi organisasional merupakan satukesatuan atau kebersamaan yang dipersepsikan oleh karyawan terhadap organisasi sebagai sebuah konsep diri yang dimiliki karyawan. Choi et al. (2014) menyatakan bahwa identifikasi organisasional telah diakui memiliki dua komponen, yaitu kebanggaan (pride) dan rasa hormat (respect). Kebanggan mengacu pada evaluasi karyawan bahwa organisasi mereka memiliki tingkat status yang tinggi dibandingkan dengan organisasi lain, sedangkan rasa hormat mencerminkan keyakinan karyawan bahwa mereka dihormati di dalam organisasi.

\section{PENGARUH KEPEMIMPINAN ETIS TERHADAP VOICE BEHAVIOR}

Resick et al. (2013) menyatakan bahwa kepemimpinan etis dapat dipercaya dengan cara menyampaikan motivasi prososial kepada pengikut dengan mempertimbangkan suara dan perspektif yang beragam serta memperlakukan orang lain dengan hormat. Terdapat dua keyakinan inti yang mendasari seseorang untuk melakukan voice behavior (Morrison, 2011). Salah satu keyakinan inti adalah apakah seseorang percaya bahwa masukan dan sarannya akan didengarkan dan ditindaklanjuti (Detert \& Burris, 2007; Morrison, 2011). Keyakinan inti lainnya adalah mengenai keamanan ketika melakukan voice behavior, dengan kata lain apakah orang-orang akan berbicara tanpa sanksi (Detert \& Burris, 2007; Morrison, 2011).

Kepemimpinan etis juga diyakini mempengaruhi kedua kepercayaan tersebut dengan memberikan kesempatan untuk menyampaikan masukan yang merupakan sinyal bagi karyawan bahwa masukan mereka dihargai (Walumbwa \& Schaubroeck, 2009). Selain itu, dengan menunjukkan rasa hormat dan perlakuan yang adil, kepemimpinan etis meningkatkan tingkat keamanan psikologis karyawan yang merupakan prediktor penting dari voice behavior (Walumbwa \& Schaubroeck, 2009). 
Selain berdasarkan logika teori yang dibangun, hal tersebut juga didukung oleh temuan empiris dari studi terdahulu yang mengungkap adanya pengaruh positif signifikan kepemimpinan etis pada voice behavior (Bai et al., 2019; Tang, 2016; Walumbwa \& Schaubroeck, 2009). Berdasarkan pemaparan logika dan hasil studi empiris terdahulu maka dirumuskan hipotesis pertama sebagai berikut:

Hipotesis 1: Kepemimpinan etis berpengaruh positif terhadap voice behavior.

\section{PENGARUH KEPEMIMPINAN ETIS TERHADAP IDENTIFIKASI ORGANISASIONAL}

Studi sebelumnya mengungkapkan faktor-faktor interpersonal dan interaksional meningkatkan identifikasi organisasional karyawan, termasuk faktor kepemimpinan dan pertukaran sosial. Pemimpin memainkan peran penting dalam kehidupan sehari-hari karyawan dalam sebuah organisasi. Dengan demikian, perilaku para pemimpin dapat membentuk bagaimana karyawan memandang hubungan dan identifikasi sosial dengan organisasi. kepemimpinan etis diperkirakan bisa meningkatkan rasa kepercayaan pengikut pada organisasi, yang memberikan kondisi yang menguntungkan bagi pengembangan identifikasi organisasional. Pengikut yang mengidentifikasi dengan organisasi cenderung tampil lebih baik dalam pekerjaan mereka (Avolio, Walumbwa, \& Weber, 2009). Hal tersebut dikarenakan pengikut yang teridentifikasi dengan organisasi menyelaraskan kepentingan mereka dengan kepentingan organisasi, atau bahkan mengorbankan kepentingan pribadi mereka sendiri untuk kepentingan kolektif (Ashforth et al., 2008; van Knippenberg, 2000; van Knippenberg \& van Schie, 2000).

Voice behavior adalah salah satu perilaku yang mungkin timbul dari identifikasi organisasional (Liu et al., 2010; Tangirala \& Ramanujam, 2008). Perilaku tersebut melibatkan secara proaktif memberi saran kepada supervisor dan manajemen untuk meningkatkan efisiensi organisasi dengan mengungkapkan keprihatinan, permasalah dan tantangan saat ini (Morrison, 2011). Karena voice behavior dimaksudkan untuk membantu kesuksesan organisasi, pengikut yang teridentifikasi dengan organisasi lebih cenderung terlibat dalam voice behavior yang konstruktif. Oleh karena itu, pengikut yang teridentifikasi dengan organisasi lebih cenderung terlibat dalam perilaku proorganisasi yang diskresioner seperti voice behavior (Van Dick, Grojean, Christ, \& Wieseke, 2006). Berdasarkan pemaparan logika dan hasil studi empiris terdahulu maka dirumuskan hipotesis kedua sebagai berikut:

Hipotesis 2: Identifikasi organisasional memediasi pengaruh positif kepemimpinan etis terhadap voice behavior.

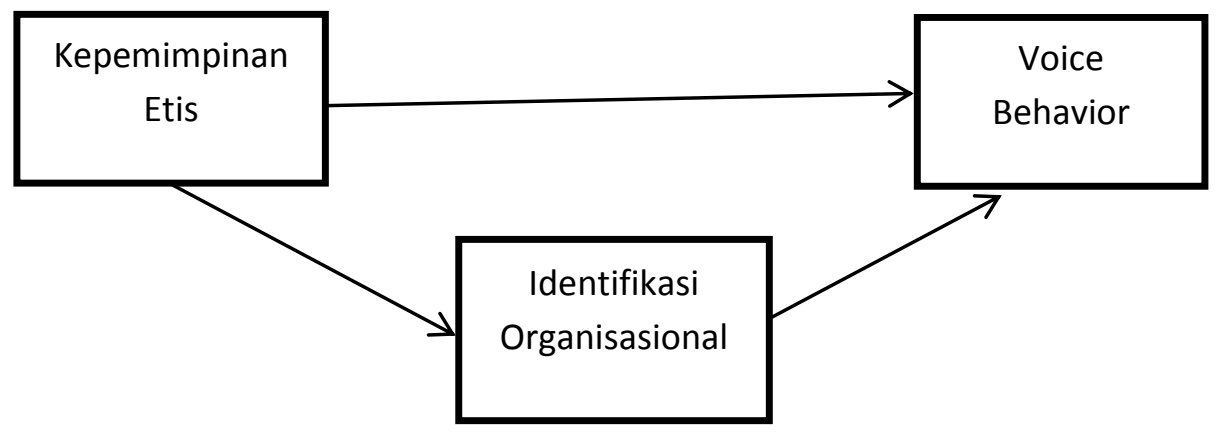

GAMBAR 1. KERANGKA PENELITIAN 


\section{METODE PENELITIAN}

Desain penelitian yang dipilih dalam penelitian ini menggunakan teknik penelitian kuantitatif. Penelitian ini menggunakan metode survei sebagai instrumen pengumpulan data. Alat pengumpulan data yang digunakan dalam penelitian ini adalah berupa kuesioner. Metode pengumpulan data menggunakan kuesioner online, yaitu data dikumpulkan dengan menyebarkan kuesioner melalui perangkat elektronik pada responden dan diisi sendiri oleh responden (Cooper \& Schindler, 2014). Populasi dalam penelitian ini meliputi organisasi/perusahaan pada sektor swasta yang bersifat profit di Indonesia. Unit analisis yang digunakan dalam penelitian ini adalah individu (karyawan). Alat analisis yang digunakan dalam penelitian adalah SPSS. Teknik analisis yang digunakan untuk pengujian hipotesis pertama adalah simple regression dan hipotesis kedua hirarchichal multiple regression.

Penelitian ini melibatkan responden yang berpartisipasi sebanyak 131 orang karyawan perusahaan swasta di Indonesia. Karakteristik responden ini selanjutnya dapat diperinci berdasarkan jenis kelamin, umur, pendidikan, dan masa kerja. Responden yang mengisi kuesioner didominasi karyawan berjenis kelamin perempuan dengan presentase 56,5\% dan karyawan perempuan sebesar 43,5\%. Dari seluruh pengisi kuesioner karyawan terbanyak adalah yang berusia antara 17- 26 tahun, yaitu sebanyak 74 orang dengan presentase $56,5 \%$. Pengisi kuesioner tersebut mayoritas memiliki masa kerja selama 1-5 tahun sebanyak 104 orang atau mencapai 79,4\% dari total responden. Mayoritas responden berpendidikan terakhir S1 sebanyak 61 orang atau sekitar $67,3 \%$.

Dalam melakukan uji validitas, peneliti menggunakan confirmatory factor analysis (CFA) dengan metode varimax rotation untuk melihat factor loading masing masing item. Adapun syarat yang harus dipenuhi yaitu nilai KMO (Keiser-Meyer-Olkin) $>0,5$ dan nilai Barlett's test memiliki signifikansi < 0,05 (Hair et al., 2014). Pengujian validitas dilakukan dalam dua putaran. Item yang nilai factor loading dibawah 0,5 dieliminasi, kemudian dilakukan uji validitas putaran kedua. Adapun hasil uji validitas putaran kedua dapat dilihat pada Tabel 1.

Tabel 1. Hasil Uji Validitas

\begin{tabular}{|c|c|c|c|c|}
\hline \multirow{2}{*}{ Variabel } & \multicolumn{3}{|c|}{ Komponen } & \multirow{2}{*}{ Keterangan } \\
\hline & 1 & 2 & 3 & \\
\hline KE3 & 0.583 & & & Valid \\
\hline KE4 & 0.577 & & & Valid \\
\hline KE5 & 0.623 & & & Valid \\
\hline KE6 & 0.541 & & & Valid \\
\hline KE7 & 0.663 & & & Valid \\
\hline KE8 & 0.760 & & & Valid \\
\hline KE9 & 0.798 & & & Valid \\
\hline KE10 & 0.528 & & & Valid \\
\hline IO1 & & & 0.749 & Valid \\
\hline 102 & & & 0.805 & Valid \\
\hline 103 & & & 0.834 & Valid \\
\hline 104 & & & 0.693 & Valid \\
\hline 105 & & & 0.764 & Valid \\
\hline VB1 & & 0.812 & & Valid \\
\hline VB2 & & 0.885 & & Valid \\
\hline
\end{tabular}




\begin{tabular}{l|l|l|l|l|l}
\hline Variabel & \multicolumn{3}{|l|}{ Komponen } & Keterangan \\
& $\mathbf{1}$ & $\mathbf{2}$ & $\mathbf{3}$ & $\mathbf{4}$ & \\
\hline VB3 & \multicolumn{5}{|c|}{0.793} \\
VB5 & 0.830 & & Valid \\
\hline
\end{tabular}

Sumber: Data Primer diolah, 2020.

Uji reliabilitas dilakukan untuk menguji presisi atau konsistensi internal itemitem pengukuran. Pengujian reliabilitas dilakukan dengan metode Cronbach's Alpha dengan memasukkan item-item yang telah valid. Item dinyatakan reliabel apabila memiliki nilai koefisien Cronbach Alpha minimal 0,6 dan semakin mendekati 1 menandakan bahwa reliabilitas semakin baik (Hair et al., 2014). Tabel 2 menunjukkan hasil uji reliabilitas seluruh variabel dalam penelitian ini.

Tabel 2. Hasil Pengujian Reliabilitas

\begin{tabular}{ccc}
\hline Variabel & Cronbach Alpha & Keterangan \\
\hline Kepemimpinan etis & 0,825 & Reliabel \\
Identifikasi organisasional & 0,888 & Reliabel \\
Voice behaviour & 0,871 & Reliabel \\
\hline
\end{tabular}

Sumber: Data Primer diolah, 2020.

\section{HASIL PENELITIAN}

Tabel 3. Hasil Pengujian Hipotesis

\begin{tabular}{|c|c|c|c|c|}
\hline Variabel & $\begin{array}{l}\text { Standardized } \\
\text { Coefficient }(\beta)\end{array}$ & Nilai $t$ & Nilai $p$ & Keterangan \\
\hline Kepemimpinan etis & 0,208 & 2.411 & 0,000 & Signifikan \\
\hline $\begin{array}{l}\text { Nilai adjusted } R^{2}=0 \\
\text { Nilai } \mathrm{F}=5.812 \\
\text { Nilai Sig }=0,017\end{array}$ & & & & \\
\hline \multicolumn{5}{|c|}{ Tahap 2 (Kepemimpinan Etis terhadap Identifikasi Organisasional) } \\
\hline Variabel & $\begin{array}{l}\text { Standardized } \\
\text { Coefficient }(\beta)\end{array}$ & Nilai $t$ & Nilai $p$ & Keterangan \\
\hline Kepemimpinan etis & 0,554 & 7.551 & 0,000 & Signifikan \\
\hline $\begin{array}{l}\text { Nilai adjusted } R^{2}=0 \\
\text { Nilai } \mathrm{F}=31,704 \\
\text { Nilai Sig }=0,000\end{array}$ & & & & \\
\hline \multicolumn{5}{|c|}{ Tahap 3 (Identifikasi Organisasional terhadap Voice Behavior) } \\
\hline Variabel & $\begin{array}{l}\text { Standardized } \\
\text { Coefficient }(\beta)\end{array}$ & Nilai $t$ & Nilai $p$ & Keterangan \\
\hline $\begin{array}{l}\text { Identifikasi } \\
\text { organisasional }\end{array}$ & 0,518 & 8,869 & 0,000 & Signifikan \\
\hline $\begin{array}{l}\text { Nilai adjusted } R^{2}=0 \\
\text { Nilai } \mathrm{F}=14.285 \\
\text { Nilai Sig }=0,000\end{array}$ & & & & \\
\hline \multicolumn{5}{|c|}{$\begin{array}{l}\text { Tahap } 4 \text { (Kepemimpinan Etis dan Identifikasi Organisasional terhadap Voice } \\
\text { Behavior) }\end{array}$} \\
\hline Variabel & $\begin{array}{l}\text { Standardized } \\
\text { Coefficient }(\beta)\end{array}$ & Nilai $t$ & Nilai $p$ & Keterangan \\
\hline $\begin{array}{l}\text { KE } \\
\text { IO }\end{array}$ & $\begin{array}{l}0,047 \\
0,290\end{array}$ & $\begin{array}{l}0,470 \\
2,878\end{array}$ & $\begin{array}{l}0,000 \\
0,000\end{array}$ & $\begin{array}{l}\text { Signifikan } \\
\text { Signifikan }\end{array}$ \\
\hline
\end{tabular}




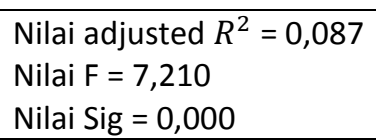

Sumber: Data Primer diolah, 2020.

Hasil penelitian seperti yang tercantum pada Tabel 3. (tahap 1) menunjukkan bahwa variabel kepemimpinan etis berpengaruh positif dan signifikan terhadap variabel voice behavior $(\theta=0,208 ; t=2,411 ; p 0,017<0,05)$. Hasil pada Tabel 3. (tahap 1) menunjukkan variabel kepemimpinan etis berpengaruh positif signifikan terhadap voice behavior. Hal tersebut menandakan bahwa, hasil pengujian terhadap hipotesis 1 terdukung dan persyaratan pertama dari Baron dan Kenny untuk hubungan mediasi terpenuhi. Selanjutnya,pada tahap 2 variabel kepemimpinan etis berpengaruh signifikan terhadap variabel identifikasi organisasional $(\theta=0,554 ; t=7,551 ; p<0,01)$, dengan demikian persyaratan kedua dari Baron dan Kenny (1986) terpenuhi.

Tabel 3 (tahap 3) menunjukkan bahwa variabel identifikasi organisasional berpengaruh positif dan signifikan terhadap variabel voice behavior $(\theta=0,518 ; \mathrm{t}=$ $8,869 ; p 0,000<0,05)$. Hal tersebut menandakan bahwa, persyaratan ketiga dari hubungan mediasi terpenuhi. Selanjutnya, pada Tabel 3. (tahap 4) menunjukkan bahwa variabel identifikasi organisasional berpengaruh positif dan signifikan terhadap variabel voice behavior $(B=0,290 ; \mathrm{t}=2,878 ; p 0,000<0,05)$. Variabel kepemimpinan etis tetap berpengaruh signifikan terhadap variabel voice behavior setelah variabel identifikasi organisasional ditambahkan ( $B=0,047 \mathrm{t}=0,470 ; p 0,000<0,05$ ).

Hasil regresi menunjukkan bahwa, pengaruh kepemimpinan etis terhadap voice behavior menjadi melemah setelah variabel pemediasi identifikasi organisasional ditambahkan. Nilai koefisien beta kepemimpinan etis terhadap voice behavior pada Tabel 4. (tahap 4), yaitu 0,047 lebih kecil dari nilai koefisien beta pada Tabel 4. (tahap 1), yaitu sebesar 0,208, setelah variabel pemediasi ditambahkan. Hal tersebut menandakan bahwa identifikasi organisasional memediasi secara parsial pengaruh antara kepemimpinan etis terhadap voice behavior, sehingga hipotesis 2 terdukung secara parsial.

\section{PEMBAHASAN}

Hipotesis 1 menyatakan bahwa kepemimpinan etis berpengaruh positif terhadap voice behavior. Hasil penelitian ini yang menyatakan dukungan terhadap hipotesis 1, sesuai dengan teori dan penelitian empiris sebelumnya (Bai et al., 2019; Tang, 2016; Walumbwa \& Schaubroeck, 2009). Hal tersebut menandakan bahwa perilaku kepemimpinan etis dapat membuat karyawan melakukan voice behavior.

Secara teoritis, hasil ini mengonfirmasi teori pembelajaran sosial dan pertukaran sosial. Sejalan dengan teori pembelajaran sosial (Wood \& Bandura, 1989) kepemimpinan etis cenderung untuk berbicara secara terbuka menentang tindakan organisasional yang tidak tepat dan menekankan untuk melakukan hal yang benar kepada karyawan. Hal tersebut kemudian mendorong perilaku yang sama pada karyawan melalui pembelajaran dengan mengamati(Walumbwa \& Schaubroeck, 2009). Selain itu, komitmen kepemimpinan etis pada komunikasi dua arah dan mendengarkan karyawan sehingga memberdayakan karyawan untuk melakukan voice behavior.

Di sisi lain, sejalan dengan teori pertukaran sosial, karyawan di bawah kepemimpinan etis lebih cenderung menganggap dirinya berada dalam hubungan pertukaran sosio-emosional berdasar pada perlakuan adil dan etis yang diterima dari 
pemimpin. Dengan demikian, para karyawan mempercayai kepemimpinan etis dan kemudian melakukan tindakan balasan dengan melakukan perilaku positif, seperti voice behavior. Hal tersebut sekaligus mendukung peneliti sebelumnya yang menemukan adanya pengaruh kepemimpinan etis terhadap voice behavior (Bai et al., 2019; Tang, 2016; Walumbwa \& Schaubroeck, 2009).

Hipotesis 2 yaitu identifikasi organisasional memediasi pengaruh kepemimpinan etis terhadap voice behavior. Penelitian ini menemukan bahwa identifikasi organisasional memediasi secara parsial pengaruh antara kepemimpinan etis terhadap voice behavior. Pengaruh mediasi tersebut bersifat parsial karena variabel kepemimpinan etis masih berpengaruh signifikan terhadap voice behavior.

Hasil tersebut mengonfirmasi teori identitas sosial, sebagai pelengkap teori pembelajaran dan pertukaran sosial dalam menjelaskan mekanisme pengaruh kepemimpinan etis terhadap voice behavior. Secara lebih spesifik, identifikasi organisasional dapat membuat pengikut untuk melakukan voice, dikarenakan individu menginternalisasi tujuan dan sasaran organisasi sebagai tujuan mereka sendiri (van Knippenberg, van Knippenberg, De Cremer, \& Hogg, 2004). Dengan demikian, efek positif yang diharapkan dari identifikasi organisasional lebih tepat untuk bentukbentuk perilaku di bawah kendali individual, seperti peran ekstra yang salah satunya adalah voice behavior. Voice behavior merupakan perilaku yang melibatkan secara proaktif memberi saran kepada supervisor dan manajemen untuk meningkatkan efisiensi organisasi dengan mengungkapkan keprihatinan, permasalah dan tantangan saat ini (Morrison, 2014). Karena voice behavior dimaksudkan untuk membantu kesuksesan organisasi, pengikut yang teridentifikasi dengan organisasi lebih cenderung terlibat dalam voice behavior yang konstruktif. Hal tersebut sejalan dengan penelitian (Riketta, 2005) yang menemukan bahwa individu yang sangat identik dengan organisasi lebih puas dan lebih cenderung menunjukkan perilaku peran ekstra. Dengan demikian, teori identitas sosial dapat melengkapi teori pertukaran sosial dan teori pembelajaran sosial dalam menjelaskan pengaruh kepemimpinan etis terhadap voice behavior.

Secara praktis, hasil penelitian menunjukan bahwa kepemimpinan etis berpengaruh positif terhadap voice behavior. Oleh karena itu, perusahaan harus menyadari bahwa kepemimpinan etis merupakan komponen penting dari sebuah organisasi yang berkelanjutan. Mengingat pengaruh positif kepemimpinan etis terhadap voice behavior, organisasi didorong untuk memilih dan melatih pemimpin etis. Misalnya, organisasi harus memilih atau mempromosikan supervisor berdasarkan integritas, standar moral, dan perhatian pada orang lain. Penelitian ini juga menemukan bahwa identifikasi organisasional memediasi pengaruh kepemimpinan etis terhadap voice behavior. Oleh karena itu, organisasi perlu mempertimbangkan untuk meningkatkan identifikasi organisasional karyawan.

\section{KESIMPULAN}

Secara keseluruhan, Penelitian ini memberikan gambaran mengenai mekanisme yang efektif dalam pengaruh kepemimpinan etis terhadap voice behavior. Hal ini menunjukan bahwa kepemimpinan etis memiliki peranan untuk membuat karyawan melakukan voice behavior. Lebih lanjut, penelitian ini juga memberikan penjelasan secara empiris terkait teori pembelajaran sosial dan pertukaran sosial, yang 
dijadikan landasan dalam menjelaskan pengaruh kepemimpinan etis terhadap voice behavior. Penelitian ini mengadopsi konseptualisasi dan operasionalisasi kepemimpinan etis yang dikembangkan oleh Brown et al. (2005), seperti yang digunakan pada beberapa penelitian. Dalam penelitian ini, kepemimpinan etis dikonsepkan sebagai satu faktor. Namun demikian, terdapat kemungkinan bahwa dua aspek kepemimpinan etis yang diidentifikasi pada penelitian kualitatif awal, yaitu moral person dan moral manager (Treviño et al., 2003) mungkin berbeda dalam mempengaruhi perilaku karyawan. (Kalshoven, Den Hartog, \& De Hoogh, 2011) mencoba untuk mengkonseptualisasi kepemimpinan etis ke dalam tujuh dimensi serta membedakan dimensi moral person dan moral manager. Penelitian selanjutnya disarankan untuk mengukur perilaku kepemimpinan etis yang memungkinkan pemisahan aspek moral person dan moral manager.

Selain itu, penelitian ini memberikan penjelasan secara teoritis dan mengonfirmasi pengaruh kepemimpinan etis pada voice behavior melalui pemediasi identifikasi organisasional dengan menggunakan teori identitas sosial. Dalam hal ini, teori identitas sosial dapat melengkapi teori pembelajaran dan pertukaran sosial untuk menjelaskan pengaruh kepemimpinan etis terhadap voice behavior. Mekanisme kepemimpinan etis dan voice behavior dalam penelitian ini hanya menguji satu variabel pemediasi, yaitu identifikasi organisasional. Sangat disarankan untuk penelitian selanjutnya melakukan pengujian mekanisme lainnya yang mampu menjelaskan pengaruh kepemimpinan etis terhadap voice behavior.

Keterbatasan dalam penelitian ini antara lain, pengumpulan data pada menggunakan metode survei yakni dengan melakukan penyebaran kuesioner melalui google form secara online. Informasi-informasi yang dapat dikumpulkan melalui kuesioner hanya berupa tulisan, maka penelitian ini tidak dapat mengeksplorasi lebih jauh keterangan-keterangan yang dapat diberikan responden. Penelitian selanjutnya dapat menggunakan metode triangulasi, yakni dengan mengkombinasikan kuesioner dengan wawancara langsung kepada responden. Hasil informasi wawancara yang berkaitan dengan hasil analisis dapat dilaporkan dan menjadi tambahan keterangan pada bagian pembahasan. Selain itu, pengumpulan data dan analisis pada penelitian ini bersifat crosssectional, yakni penelitian yang dilakukan hanya pada satu frekuensi atau titik tertentu. Penelitian selanjutnya dapat menguji pengaruh kepemimpinan etis pada voice behavior melalui identifikasi organisasional dengan memanfaatkan metode studi yang bersifat longitudinal untuk mengkonfirmasi konsistensi pengaruh kepemimpinan etis pada voice behavior dari waktu ke waktu.

\section{DAFTAR PUSTAKA}

Ashforth, B. E., Harrison, S. H., \& Corley, K. G. (2008). Identification in organizations: An examination of four fundamental questions. Journal of Management, 34(3), 325374.

Avolio, B. J., Walumbwa, F. O., \& Weber, T. J. (2009). Leadership: Current theories, research, and future directions. Annual Review of Psychology, 60, 421-449.

Bai, Y., Lin, L., \& Liu, J. T. (2019). Leveraging the employee voice: a multi-level social learning perspective of ethical leadership. International Journal of Human Resource Management, 30(12), 1869-1901. Routledge. Retrieved from 
http://dx.doi.org/10.1080/09585192.2017.1308414

Brown, M. E., Treviño, L. K., \& Harrison, D. A. (2005). Ethical leadership: A social learning perspective for construct development and testing. Organizational Behavior and Human Decision Processes, 97(2), 117-134.

Demirtas, O. (2013). Ethical Leadership Influence at Organizations: Evidence from the Field. Journal of Business Ethics, 126(2), 273-284.

Detert, J. R., \& Burris, E. R. (2007). Leadership behavior and employee voice: Is the door really open? Academy of Management Journal, 50(4), 869-884.

Van Dick, R., Grojean, M. W., Christ, O., \& Wieseke, J. (2006). Identity and the extra mile: Relationships between organizational identification and organizational citizenship behaviour. British Journal of Management, 17(4), 283-301.

Ellemers, N., De Gilder, D., \& Haslam, S. A. (2004). Motivating individuals and groups at work: A social identity perspective on leadership and group performance. Academy of Management Review, 29(3), 459-478.

van Gils, S., Van Quaquebeke, N., van Knippenberg, D., van Dijke, M., \& De Cremer, D. (2015). Ethical leadership and follower organizational deviance: The moderating role of follower moral attentiveness. Leadership Quarterly, 26(2), 190-203. Elsevier Inc. Retrieved from http://dx.doi.org/10.1016/j.leaqua.2014.08.005

Kalshoven, K., Den Hartog, D. N., \& de Hoogh, A. H. B. (2013). Ethical leadership and followers' helping and initiative: The role of demonstrated responsibility and job autonomy. European Journal of Work and Organizational Psychology, 22(2), 165181.

Kalshoven, K., Den Hartog, D. N., \& De Hoogh, A. H. B. (2011). Ethical leadership at work questionnaire (ELW): Development and validation of a multidimensional measure. Leadership Quarterly, 22(1), 51-69. Elsevier B.V. Retrieved from http://dx.doi.org/10.1016/j.leaqua.2010.12.007

van Knippenberg, D., van Knippenberg, B., De Cremer, D., \& Hogg, M. A. (2004). Leadership, self, and identity: A review and research agenda. Leadership Quarterly, 15(6), 825-856.

LePine, J. A., \& Van Dyne, L. (1998). Predicting voice behavior in work groups. Journal of Applied Psychology, 83(6), 853-868.

Lu, C. S., \& Lin, C. C. (2014). The Effects of Ethical Leadership and Ethical Climate on Employee Ethical Behavior in the International Port Context. Journal of Business Ethics, 124(2), 209-223.

Mayer, D. M., Kuenzi, M., \& Greenbaum, R. L. (2010). Examining the Link Between Ethical Leadership and Employee Misconduct: The Mediating Role of Ethical Climate. Journal of Business Ethics, 95(SUPPL. 1), 7-16.

Morrison, E. W. (2011). Employee voice behavior: Integration and directions for future research. Academy of Management Annals, 5(1), 373-412.

Morrison, E. W. (2014). Employee Voice and Silence. Annual Review of Organizational 
Psychology and Organizational Behavior, 1, 173-197.

Newman, A., Kiazad, K., Miao, Q., \& Cooper, B. (2014). Examining the Cognitive and Affective Trust-Based Mechanisms Underlying the Relationship Between Ethical Leadership and Organisational Citizenship: A Case of the Head Leading the Heart? Journal of Business Ethics, 123(1), 113-123.

Resick, C. J., Hargis, M. B., Shao, P., \& Dust, S. B. (2013). Ethical leadership, moral equity judgments, and discretionary workplace behavior. Human Relations, 66(7), 951-972.

Riketta, M. (2005). Organizational identification: A meta-analysis. Journal of Vocational Behavior, 66(2), 358-384.

Stouten, J., van Dijke, M., Mayer, D. M., De Cremer, D., \& Euwema, M. C. (2013). Can a leader be seen as too ethical? The curvilinear effects of ethical leadership. Leadership Quarterly, 24(5), 680-695. Elsevier Inc. Retrieved from http://dx.doi.org/10.1016/j.leaqua.2013.05.002

Tang, P. M. (2016). Ethical leadership in social enterprises : multilevel investigation of its influence on team and individual prosocial voice Terms of Use The copyright of this thesis is owned by its.

Treviño, L. K., Brown, M., \& Hartman, L. P. (2003). A qualitative investigation of perceived executive ethical leadership: Perceptions from inside and outside the executive suite. Human Relations, 56(1), 5-37.

Tu, Y., \& Lu, X. (2016). Do Ethical Leaders Give Followers the Confidence to Go the Extra Mile? The Moderating Role of Intrinsic Motivation. Journal of Business Ethics, 135(1), 129-144. Springer Netherlands. Retrieved from http://dx.doi.org/10.1007/s10551-014-2463-6

Walumbwa, F. O., Mayer, D. M., Wang, P., Wang, H., Workman, K., \& Christensen, A. L. (2011). Linking ethical leadership to employee performance: The roles of leadermember exchange, self-efficacy, and organizational identification. Organizational Behavior and Human Decision Processes, 115(2), 204-213. Elsevier Inc. Retrieved from http://dx.doi.org/10.1016/j.obhdp.2010.11.002

Walumbwa, F. O., \& Schaubroeck, J. (2009). Leader Personality Traits and Employee Voice Behavior: Mediating Roles of Ethical Leadership and Work Group Psychological Safety. Journal of Applied Psychology, 94(5), 1275-1286.

Wood, R., \& Bandura, A. (1989). Social Cognitive Theory of Organizational Management Published by: Academy of Management Linked references are available on JSTOR for this article: Social Cognitive Theory of Organizational Management University of New South Wales. Academy of Management Review, 14(3), 361-384.

Yang, C. (2014). Does Ethical Leadership Lead to Happy Workers? A Study on the Impact of Ethical Leadership, Subjective Well-Being, and Life Happiness in the Chinese Culture. Journal of Business Ethics, 123(3), 513-525. 